\title{
Studi Analisis Pengaruh Perubahan Posisi Terhadap Efisiensi Panel Surya LPJU By Pass Ngurah Rai
}

\author{
I Ketut Suantika ${ }^{1}$, Wayan Rinas ${ }^{2}$, I Made Suartika ${ }^{3}$ \\ Program Studi Teknik Elektro, Fakultas Teknik, Universitas Udayana Denpasar - Bali

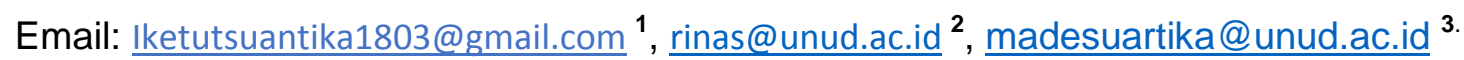

\section{ABSTRAK}

Pemanfaatan sinar matahari sebagai sumber energi listrik terbarukan dengan menggunakan photovoltaic (PV) sudah banyak dilakukan oleh instansi swasta maupun negeri. Salah satunya Pemerintah Kabupaten Badung. Sumber daya listrik untuk Lampu Penerangan Jalan Utama (LPJU) dengan jumlah tiang lampu 305 yang terpasang sepanjang jalan By Pass I Gusti Ngurah Rai. Penelitian ini menganalisis pengaruh perubahan posisi terhadap efsiensi panel surya LPJU. Simulasi pada penelitian ini menggunakan software PVSyst dan dibandingkan dengan hasil pengukuran secara riil untuk memperoleh posisi solar cell yang dapat menghasilkan daya output yang optimal dan nilai efisiensinya lebih baik. Hasil penelitian perbandingan pengukuran rill dengan simulasi PVSyst, pada zona 1 diperoleh pembangkitan energi maksimum sebesar 60,42 kWh, 186,40 kWh, pada zona 2 sebesar 72,54 kWh, 186,40 kWh, pada zona 3 sebesar 33,97 kWh,186,40 kWh, pada zona 4 sebesar $61,52 \mathrm{kWh}, 186,40$ kWh. Hasil simulasi PVSyst menunjukkan daya output solar cell lebih tinggi dari pada pengukuran secara rill dengan arah yang berbeda dan nilai efisiesin yang di dapatkan lebih baik dari pada pengukuran rill sebelumnya.

Kata kunci: (LPJU), Solar cell, software PVSyst.

\begin{abstract}
Utilization of sunlight as a source of renewable electrical energy by using photovoltaic (PV) has been done by many public and private agencies. One of them is Badung Regency Government. Power source for Main Street Lighting (LPJU) with the number of lamp posts 305 installed along the road By Pass I Gusti Ngurah Rai. This study analyzed the effect of position change on the efficiency of LPJU solar panel. The simulation of this research using PVSyst software and compared with real measurement result to get the position of solar cell that can produce optimal output power and better efficiency value. The result of comparison of rill measurement with PVSyst simulation, in zone 1 obtained maximum energy generation of 60,42 $\mathrm{kWh}, 186,40 \mathrm{kWh}$, at zone 2 equal to $72,54 \mathrm{kWh}, 186,40 \mathrm{kWh}$, at zone 3 equal to 33,97 $\mathrm{kWh}$, $186.40 \mathrm{kWh}$, in zone 4 of $61.52 \mathrm{kWh}, 186.40 \mathrm{kWh}$. The PVSyst simulation results show that the solar cell output power is higher than the rear measurement in different directions and the efisiesin value obtained is better than the previous rill measurement.

Keywords: $\quad$ (LPJU), Solar cell, PVSyst software
\end{abstract}

\section{PENDAHULUAN}

Pengembangan pemanfaatan sinar matahari sebagai sumber energi listrik dengan menggunakan photovoltaic (PV) / solar cell sudah banyak dilakukan, hingga kini instansi pemerintahan dan pendidikan diajak untuk memanfaatkan sumber energi terbarukan sebagai gerak pemerintah untuk membangun pembakit listrik ramah lingkungan. Banyak peneliti melakukan penelitian terkait pemanfaatan sinar matahari sebagai sumber energi listrik dengan menggunakan photovoltaic (PV) I solar cell. Penelitian yang dilakukan oleh I Wayan Hendra Setiawan [1] dengan judul “
Menganalisa nilai Ekonomi dan teknik Pengoperasian Penerangan lampu Jalan Umum di sepanjang Jln By Pass I Gusti Ngurah Rai yang mengunakan solar cell". Hasil penelitian ini dijelaskan analisis nilai ekonomis dan teknik LPJU sepanjang jalan By Pass I Gusti Ngurah Rai untuk mengetahui pengaruh perbedaan arah kemiringan solar cell terhadap energi yang dihasilkan oleh LPJU solar cell (PV).

"Sistem Penerangan lampu Jalan dan taman disekitar pedopo dan parkir direncanakan akan menggunakan solar cell, Pada penelitian tersebut dijelaskan sistem penerangan taman dan jalan di 
kampus Universitas Sumatra Utara akan dirancanakan menggunakan solar cell, dari perencanaan ini didapatkan hasil untuk mengurangi tenaga listrik yang tidak ramah lingkungan contoh batu bara dan disel [2].

Penelitian " menganalisa nilai ekonomis untuk penerangan jembatan suramadu dengan mengunakan solar cell". Hasil penelitian ini dijelaskan analisa dari segi teknis mengenai pencahayaan yang diperlukan pada Jembatan Suramadu, serta dari segi ekonomis dan juga analisis tentang biaya investasi peralatan lampu penerangan jalan solar cell.[3]

Ketiga penelitian yang telah dilakukan tersebut hanya membahas tentang efisiensi penggunaan solar cell untuk mengurangi konsumsi penggunaan tenaga surya. Berdasarkan hal tersebut, maka penekanan pada penelitian ini adalah analisa perbandingan daya yang dihasilkan dengan pengukuran rill dengan menggunakan software PVSyst dan mencari nilai efisiensi yang terbaik tanpa memperhatikan nilai estetika.

\section{KAJIAN PUSTAKA}

\subsection{Fungsi Lampu Jalan Umum}

Penerangan perlu dipasang disetiap jalan baik itu di tengah,kanan maupun kiri,fungsi dari lampu jalan untuk menerangi jalan disaat malam,memperindah pandagan bagi pengguna jalan dan lingkungan sekitar. Pemasangan lampu itu wajib untuk K3,baik itu dijalan layang,anderpas,jalan bawah tanah maupun jembatan.

\subsection{Mecari arah kemiringan dan nilai efisiensi solar cell}

1. Efisiensi panel surya adalah perbandingan daya input dengan daya output dari panel surya tersebut. Daya input didapat dari besarnya intensitas radiasi matahari, sehingga didapat efisiensi sebesar. Perhitungan ini menggunakan persamaan (2.1)

$$
\eta=\frac{\text { Output }}{\text { Input }} \times 100 \%
$$

2. Menghitung kemiringan solar cell LPJU yang sesuai, dengan menggunakan acuan letak geografis (latitude) dari lokasi penelitian. Perhitungan ini menggunakan persamaan (2.2)

$$
a=90^{\circ}-\text { lat }+\delta(\text { N hemisphere }) ; 900+\text { lat }-\delta(\text { Shemisphere })
$$

Dimana :

lat; dalam satuan derajat, latitude adalah garis lintang lokasi terpasangnya panel surya.

$\delta$ : deklinasi sudut matahari $\left(23,45^{\circ}\right)$

$23,45^{\circ}$ kemiringan bidang orbit bumi terhadap matahari, matahari mempunyai tinggi yang berpariasi setiap detik, menit atau waktu. Mengetahui ketingaan maksimum dari matahari dalam derajat atau alfa $(\alpha)$, dapat mengunakan persamaan diatas.

\subsection{Jenis Lampu Penerangan Jalan Umum}

1. Lampu LVD (Low Voltage Discharge) mempunyai tiga bagian penting, yaitu ballast dengan frekuensi tinggi, sebuah lampu dan kumparan induksi.

2. Lampu HPS (High Pressure Sodium) Lampu HPS lampu yang lebih kecil dan berwana kebiru-biruan, oranye dan kemerah jambuan,dan mengandung unsur tambahan yaitu air raksa.

3. Lampu LED (Light Emiting Diode) LED lampu LED memiliki dioda lainnya, LED juga terdiri dari bahan semikonduktor $P$ dan N. apa bila lampu LED dialiri ars listrik maka lampu LED akan merubah energi listrik Menjadi Energi cahaya.

\subsection{Solar cell}

Energi listrik dapat dibangkitkan dengan mengubah cahaya matahari menjadi photovoltaic (PV). Dengan proses Photo yang berati cahaya dan voltaic berarti tegangan. Proses ini akan merubah cahaya matahari menjadi energi listrik arus searah, lalu akan dirubaha dengan proeses inverter atau merubaha energi arsu searah menjadi arus bolak balik.

Material semikonduktor yang paling utama adalah silikon yang dilapisi oleh tambahan khusus sebagai bahan dari Photovoltaic cell. Apabila sollar cell terkena cahaya matahari maka elektron dan atom akan terlepas dari silikon dan mengalir membentuk sirkuit energi listrik, sehinggan energi listrik dapat dibangkitkan,solar cell (PV) selalu dirancang untuk Mengubah cahaya matahari menjadi energi listrik,baik itu energi listrik arus searah maupun energi arus bolak balik dapat diatur sesuai dengan apa yang kita inginkan.

\subsection{PVSyst}

PVSyst merupakan paket software/ perangkat lunak yang digunakan untuk 
proses pembelajaran, pengukuran, dan analisan data dari sistem PLTS secara lengkap. PVSyst dikembangkan oleh Universitas Geneva, yang terbagi ke dalam sistem terinterkoneksi jaringan (gridconnected), sistem berdiri sendiri (standalone) sistem pompa (pumping), dan jaringan arus searah untuk transportasi publik (DC-grid). PVSyst juga dilengkapi database dari sumber data meteorologi yang luas dan beragam, serta data komponen-komponen PLTS.

Untuk dapat menaganalisa peningkatan output panel surya LPJU By Pass Ngurah Rai dengan merubah posisi kemiringan, digunakan fitur desain proyek (project design) pada PVSyst. Pada fitur ini simulasi akan dijalankan dengan cara membuat terlebih dahulu desain dari sistem PLTS sesuai dengan sistem terpasang. Langkah dalam membuat desain proyek adalah sebagai berikut:

1. Menetapkan proyek Dengan cara menentukan jenis proyek atau jenis PLTS dalam hal ini dipilih grid-connected. Dilanjutkan dengan membuat proyek baru dan mendefinisikan proyek seperti nama proyek, lokasi, dan data meteorologi.

2. Menetapkan perbedaan sistem (system variant). Dengan cara menentukan orientasi terlebih dahulu seperti jenis penyangga panel surya, kemiringan panel, dan azimuth, lalu menentukan sistem PLTS, dengan memilih parameter opsional, seperti pemilihan profil horizon sesuai lokasi, yang dapat ditambahkan dengan impor data dari software lain, seperti dari Solmetric SunEye.

3. Menjalankan simulasi untuk mendapatkan hasil simulasi

\section{METODE PENELITIAN}

Penelitian ini dilakukan di Jalan By Pass I Gusti Ngurah Rai sepanjang 9,4 km berawal dari persimpangan Jalan I Gusti Ngurah Rai, Jalan Tol Bali Mandara dan Jalan Waringin hingga persimpangan antara Jalan By Pass I Gusti Ngurah Rai, Jalan Pratama, jalan Nusa Dua dan Jalan Gopala pada bulan Oktober 2016.dengan data penelitian yang bersumber dari Data Dinas Perhubungan, Komunikasi dan Informatika dan data yang bersumber dari literatur dan Jenis data yang digunakan berupa data primer dan data sekunder.

\subsection{Alur Analisis}

Pada penelitian ini akan dilaksanakan dengan tahapan-tahapan sebagai berikut:

1. Observasi awal lampu Penerangan Jalan Umum (LPJU) solar cell di Jalan By Pass I Gusti Ngurah Rai untuk mengetahui spesifikasi, sistem, dan denah pemasangan unit LPJU, dengan cara mengumpulkan data dan dokumentasi sebagai acuan untuk memperoleh data selanjutnya.

2. Menentukan letak geografis (latitude) LPJU solar cell dengan cara pengukuran secara langsung menggunakan GPS pada lokasi penelitian di Jalan By pass I Gusti Ngurah Rai, Pengukuran dilakukan di beberapa titik LPJU pada setiap zona.

3. Menganalisis arah dari solar cell pada setiap LPJU yang dikelompokan menjadi beberapa zona agar memudahkan penilaian daerah mana yang menghasiIkan daya output yang paling baik

4. Menghitung kemiringan solar cell LPJU yang sesuai, dengan menggunakan acuan letak geografis dari lokasi penelitian. Perhitungan ini menggunakan persamaan (2.2).

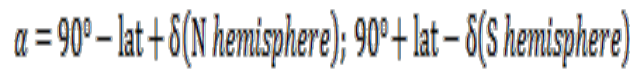

5. Melakukan simulasi menggunakan program PVSyst untuk mendapatkan nilai daya output maksimal yang mampu dilakukan oleh solar cell LPJU pada lokasi penelitian.

6. Menganalisis perbandingan daya output yang dihasilkan oleh solar cell LPJU secara riil dari perhitungan langsung.

7. dengan daya output maksimal sesuai lokasi terpasang yang diperoleh dari hasil simulasi program PVSyst.

8. Menghitung dan menganalisa perbandingkan efisiensi LPJU By Pass Ngurah rai [5], setiap zona pada pengukuran riil dan setiap zona dari hasil simulasi program PVSyst. Perhitungan ini menggunakan persamaan (2.1).

\subsection{Tahapan pembuatan simulasi}

$$
\begin{aligned}
& \text { Ef } \text { isiensi }=\frac{\text { Pout }}{\text { Pin }} \times 100 \% \\
& \text { pan pembuatan simulasi }
\end{aligned}
$$

Tahapan atau langkah - langkah pembuatan menggunakan program simulasi PVSyst akan dijelaskan pada sub bab ini. Berikut tahapannya

1. Membuka program PVSyst, lalu memilih project design. 


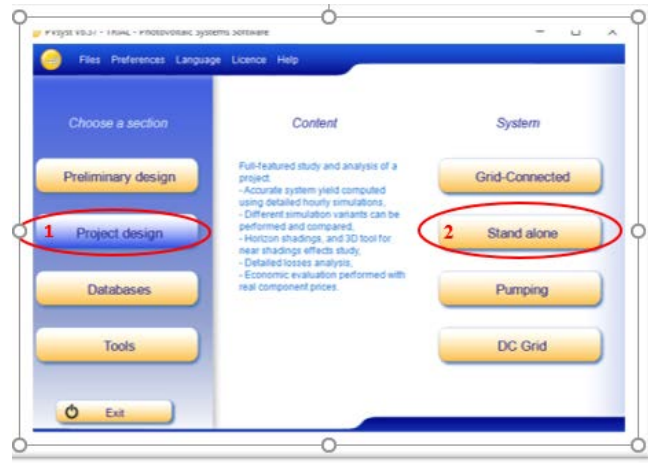

Gambar 2. Tampilan Menu Awal Program PVSyst

2. Memilih sistem project design sesuai dengan yang terpasang, yaitu stand alone

3. Membuat Nama Proyek: LPJU By Pass I Gst Ngurah rai.

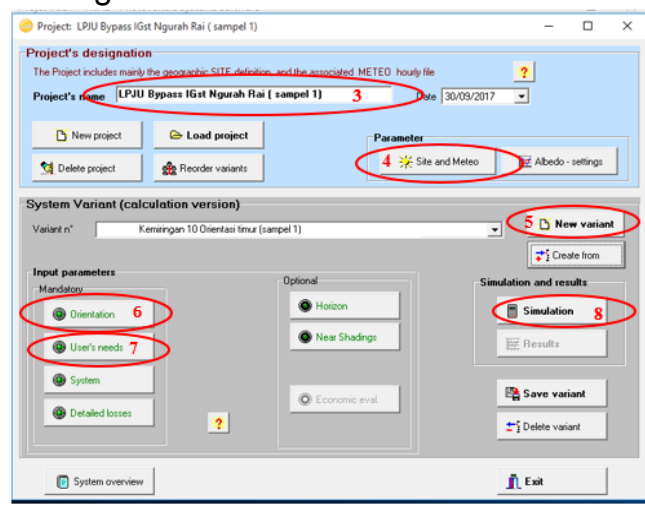

Gambar 3. Tampilan Menu Project Designation

4. Menentukan parameter Site and Meteo. Di tahap ini kita akan memasukan letak koordinat dari lokasi LPJU solar cell By pass I Gusti Ngurah Rai, agar lebih akurat kita gunakan fitur Interactive Map, setelah menandai lokasi lalu klik Import agar data lokasi koordinat yang kita tandai masuk ke program PVSyst

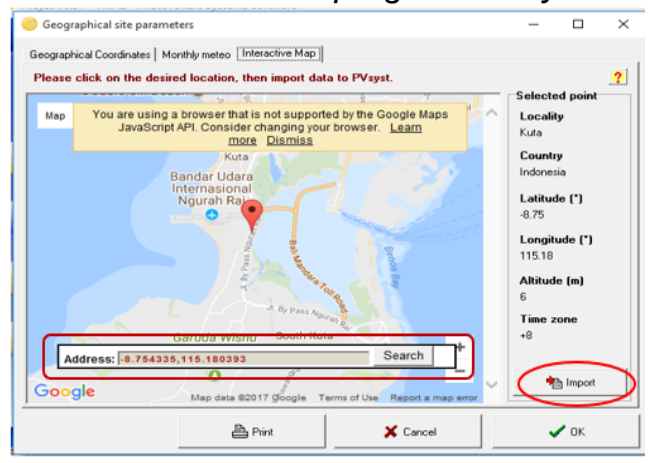

Gambar 4. Menu Parameter Site Meteo

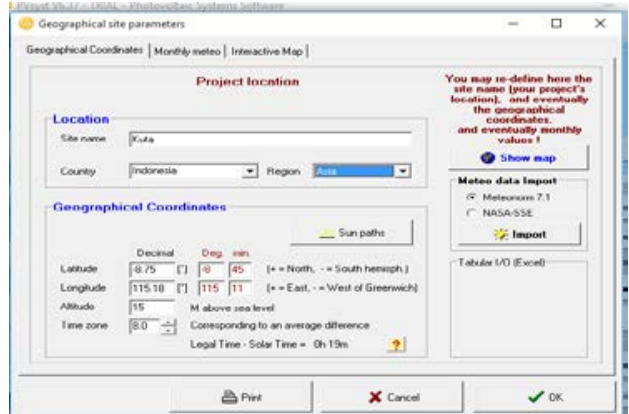

Gambar 5. Tampilan Menu Parameter Site \& Meteo

Setelah proses import berhasil maka pada kolom Geographical Coordinates akan otomatis terisi dan data acuan meteorologi atau nilai Latitude sesuai letak LPJU solar cell By pass I Gusti Ngurah Rai dapat diketahui.

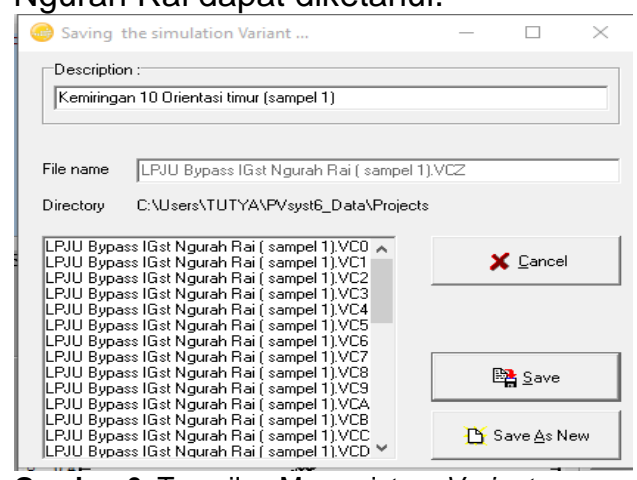

Gambar 6. Tampilan Menu sistem Variant

5. Tahap selanjutnya adalah mengisi System Variant dari PLTS, ditahap ini langkah pertama adalah pemberian nama variant.

6. Selanjutnya menentukan Orientasi PLTS

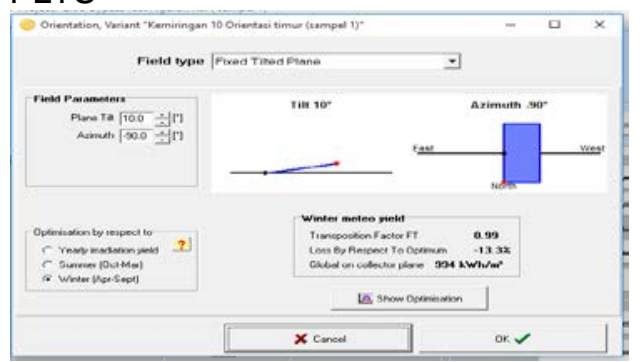

Gambar 7. Tampilan Pengaturan Orientasi dan Kemiringan Panel

7. Tahap selanjutnya adalah mengisi User's needs dari PLTS, ditahap ini langkah untuk menentukan berapa banyak jumlah beban yang akan dibebankan ke PLTS sollar cell yang akan dirancang dan berapa lama beban akan on atau bekerja. 


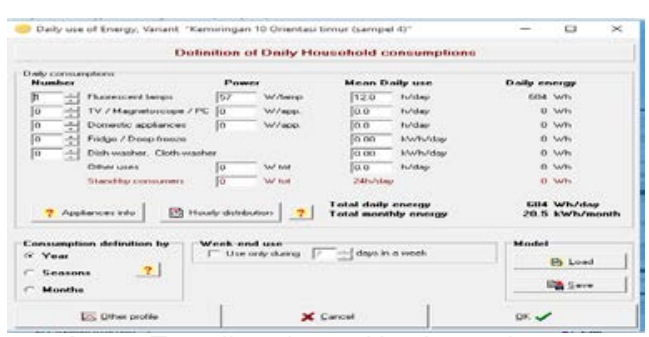

Gambar 8. Tampilan sistem User's needs

8. Setelah memasukan semua data sesuai dengan kondisi PLTS, maka tahap terakhir, yaitu menjalankan simulasi.

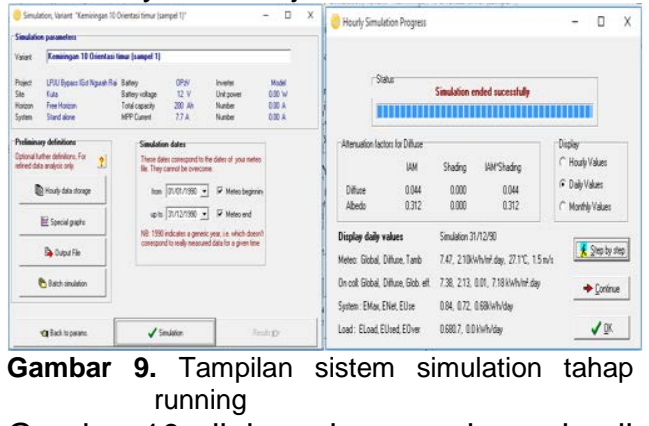

Gambar.10 di bawah merupkana hasil dari simulasi PVSyst, kemudian agar memperoleh data yang diinginkan klik report, akan memuculkan data dari hasil simalation PVSyst.

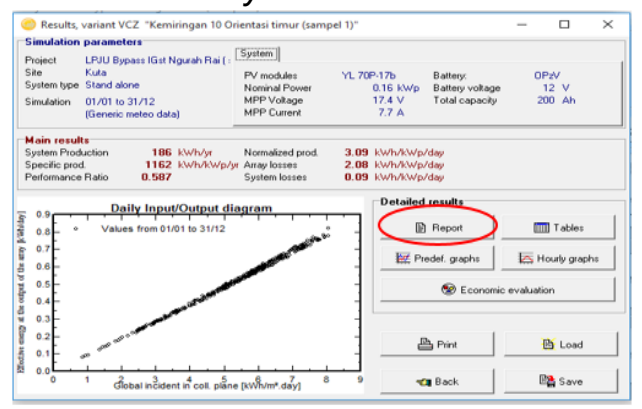

Gambar 10. Tampilan sistem simulation sesudah running

\section{HASIL DAN PEMBAHSAN}

\subsection{Hasil}

Berdasarkan perbandingan hasil pembangkitan daya pengukuran riil dengan simulasi PVSyst menunjukan hasil daya output solar cell dengan simulasi PVSyst lebih tinggi dibandingkan dengan pengukuran secara rill dengan arah yang berbeda dan untuk analisa efisiensi untuk LPJU By Pass Ngurah rai menujukan efisiensi produksi daya pada pengukuran riil terendah pada zona 3 yaitu 1,57 \%, dikarenakan produksi riil tidak optimal dan posisi solar cell menghadap ke selatan. Sedangkan efisiensi panel surya LPJU By Pass Ngurah rai yang terbesar terdapat pada simulasi PVSyst yang mengarah ke utara yaitu sebesar 19,2\% di setiap zona Hal ini disebabkan perjalan rotasi matahari dari terbit hingga tenggelam berada di utara pulau Bali yang terletak diselatan garis katulistiwa.

\subsection{Pembahasan}

Untuk mendapatkan hasil dan data dari pengaruh perubahan posisi terhadap daya yang dihasilkan oleh PV dengan simulasi dan nilai efisiensi dari pengukuran riil dan simulasi PVSyst LPJU solar cell By Pass Ngurah Rai diperoleh dengan membagi wilayah penelitian menjadi empat zona [6], setiap zona penelititan dilakukan dengan membandingkan hasil nilai daya output rill dengan hasil nilai daya output yang diperoleh dari hasil simulasi PVSyst.

\subsubsection{Hasil Perbandingan daya, pengukuran riil dengan simulasi PVSyst.}

Pada Tabel 1 dan Gambar 6 terlihat Perbandingan hasil pembakitan daya dari solar cell by pass I Gusti Ngurah Rai yang diukur secara riil dengan hasil simulasi PVSyst dilihat bahwa hasil simulasi PVSyst menunjukkan daya output solar cell lebih tinggi dari pada pengukuran secara rill dengan arah yang berbeda.

Tabel 1. Perbandingan pengukuran rill daya output solar cell dengan simulasi PVSyst setahun.

\begin{tabular}{|l|l|c|c|c|c|}
\hline \multirow{2}{*}{ No } & Zona & \multicolumn{4}{|c|}{ Hasil pengukuran dan arah sollar cell $(k W h)$} \\
\cline { 3 - 6 } & $\begin{array}{c}\text { Pengukuran } \\
\text { riil }\end{array}$ & $\begin{array}{c}\text { Arah } \\
\text { sollar cell }\end{array}$ & $\begin{array}{c}\text { Hasil } \\
\text { simulasi } \\
\text { PVSyst }\end{array}$ & $\begin{array}{c}\text { Arah } \\
\text { sollar cell }\end{array}$ \\
\hline I & 1 & 60,42 & Barat laut & 186,40 & Utara \\
\hline II & 2 & 72,54 & Barat & 186,40 & Utara \\
\hline III & 3 & 33,97 & Selatan & 186,40 & Utara \\
\hline IV & 4 & 61,52 & Barat daya & 186,40 & Utara \\
\hline
\end{tabular}

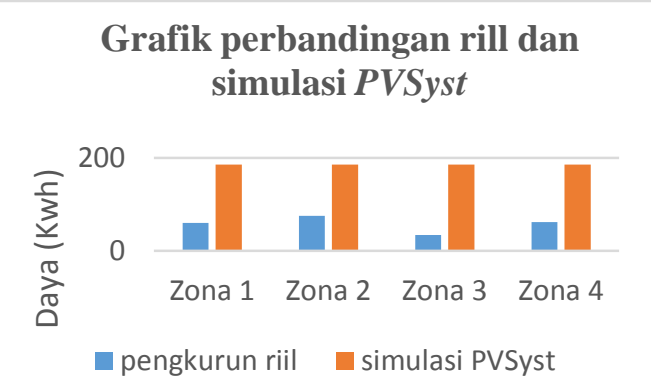

Gambar 11. Perbandingan pengukuran rill daya output solar cell dengan simulasi PVSyst

\subsubsection{Analisa efisiensi untuk LPJU By Pass Ngurah rai}

Pada Tabel 2 dan Gambar 12 terlihat perbandingan efisiensi dari LPJU solar cell by pass I Gusti Ngurah Rai, yang diukur secara riil dengan hasil simulasi PVSyst 
Berdasarkan Tabel 2 menujukan efisiensi produksi daya pada pengukuran riil terendah pada zona 3 yaitu 1,57 \%, dikarenakan produksi riil tidak optimal dan posisi solar cell menghadap ke selatan. Sedangkan efisiensi panel surya LPJU By Pass Ngurah rai yang terbesar terdapat pada simulasi PVSyst yang mengarah ke utara yaitu sebesar 19,2 \% di setiap zona. Hal ini disebabkan perjalan rotasi matahari dari terbit hingga tenggelam berada di utara pulau Bali yang terletak diselatan garis katulistiwa

Tabel 2.Perbandingan efisiensi produksi rill solar cell dengan simulasi PVSyst setahun

\begin{tabular}{|l|c|c|c|c|c|c|c|}
\hline & & \multicolumn{5}{|c|}{ Efisiensi panel surya LPJ By Pass Ngura Rai } \\
\hline No & Zona & Riil & Arah & Simulasi & Arah & $\begin{array}{r}\text { simulasi } \\
\text { (tertinggi) }\end{array}$ & Arah \\
\hline I & 1 & $2,78 \%$ & Barat laut & $19,01 \%$ & Barat laut & $19,2 \%$ & Utara \\
\hline II & 2 & $3,35 \%$ & Barat & $18,01 \%$ & Barat & $19,2 \%$ & Utara \\
\hline II & 3 & $1,57 \%$ & Selatan & $17.01 \%$ & Selatan & $19,2 \%$ & Utara \\
\hline IV & 4 & $2,84 \%$ & Barat daya & $18,01 \%$ & Barat daya & $19.2 \%$ & Utara \\
\hline
\end{tabular}

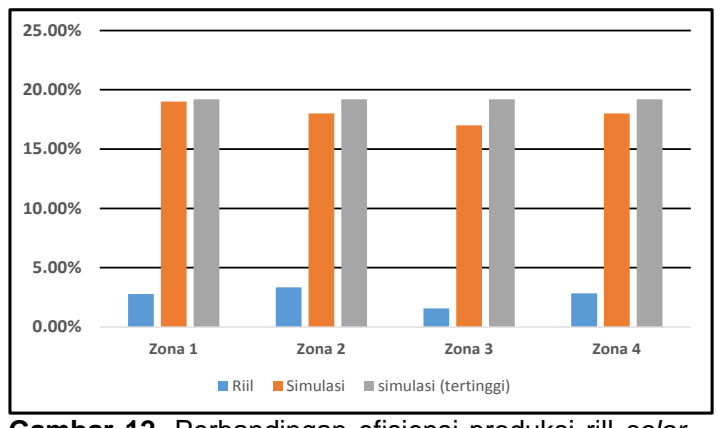

Gambar 12. Perbandingan efisiensi produksi rill solar cell dengan simulasi PVSyst setahun.

\section{KESIMPULAN}

Pengaruh dari perubahan posisi solar cell adalah pada zona 1 dengan sudut $10^{\circ}$ arah pemasangan ke barat laut menghasilkan daya sebesar 60,42 kWh sedangkan arah simulasi PVSyst ke utara menghasilkan daya sebesar 186,40 kWh, zona 2 dengan sudut $10^{\circ}$ arah pemasangan ke barat menghasilkan daya sebesar 72,54 kWh sedangkan arah simulasi PVSyst ke utara menghasilkan daya sebesar 186,40 kWh, zona 3 dengan sudut $10^{\circ}$ arah pemasangan ke selatan menghasilkan daya sebesar 33,97 kWh sedangkan arah simulasi PVSyst ke utara menghasilkan daya sebesar 186,40 kWh dan zona 4 dengan sudut $10^{\circ}$ arah pemasangan ke barat daya menghasilkan daya sebesar 61,52 kWh sedangkan arah simulasi PVSyst ke utara menghasilkan daya sebesar 186,40 kWh.
Nilai efisiensi dari pengukuran riil pada zona 1 sebesar 2,78\%, zona 2 sebesar $3,35 \%$, zona 3 sebesar $1,57 \%$, zona 4 sebesar $2.84 \%$. Sedangkan nilai efisiensi dari hasil simulasi PVSyst dari 4 zona yang semua mengarah utara, semua zona menunjukan nilai efisiensi sebesar 19,2\%. $\mathrm{Hal}$ ini disebabkan perjalan rotasi matahari dari terbit hingga tenggelam berada di utara pulau Bali yang terletak diselatan garis katulistiwa. Jadi untuk hasil simulasi PVSyst yang mempunyai efisiensi yang optimal menghadap utara.

\section{DAFTAR PUSTAKA}

[1] Setiawan, I W.H. 2015, "Analisis Teknis dan Ekonomis Pengoperasian Penerangan Jalan Umum Menggunakan Solar Cell untuk Kebutuhan Penerangan di Jalan By Pass I Gusti Ngurah Rai" (tugas akhir).Bali : Universitas Udayana.

[2] Sihombing, D.T.B. 2013. "Perencanaan Sistem Penerangan Jalan Umum dan Taman di Areal Kampus Usu dengan Menggunakan Teknologi Tenaga Surya (Aplikasi di Areal Pendopo dan Lapangan Parkir)" (tugas akhir).Bali: Universitas Sumatera Utara

[3] Sarwito, S. Kusuma, I.R. Setiawan, D. 2010. Analisa Teknis Dan Ekonomis Penerapan Sel Surya Untuk Kebutuhan Penerangan Jembatan Suramadu Jurusan Teknik Sistem Perkapalan. Surabaya : Institut Teknologi Surabaya..

[4]. Kusumayogo, E. Wibawa, U. Suyono, H. 2013. Analisis Teknis Dan Ekonomis Penerapan Penerangan Jalan Umum Solar Cell Untuk Kebutuhan Penerangan Di Jalan Tol Darmo Surabaya. Malang: Universitas Brawijaya..

[5] I Nyoman Budiastra. Cokorde Gede Indra Partha 2017. Pengaruh Efisiensi Panel Surya Terhadap Penambahan Cermin Datar

[6] Anonim. 2012. Laporan Pertanggung Jawaban pengadaan Lampu penerangan jalan solar cell by pass I Gusti Ngurah Rai. Mangupura : DISHUBKOMINFO. 